\title{
DESIGNING AN IDEAL MODEL FOR THE INDONESIA SOCIAL SECURITY ADMINISTRATION BODY (BPJS) RELATED TO HEALTH FUND MANAGEMENT
}

\author{
Djuwityastuti, Wida Astuti \\ Faculty of Law, University of Sebelas Maret \\ Email: djuwityastuti@ staff.uns.ac.id
}

\begin{abstract}
Establishment of the Social Security Administration Body (BPJS) is one manifestation of the nation goals in achieving certainty in protection and social welfare for all citizens. By studying legal foundation as the legality of the establishment of BPJS relating to governance of social security in some countries, the fact shows that the institutional body of BPJS still has some drawbacks. This research is funded by the Ministry of Research, Technology, and Higher Education, the article presents some ideal forms of institutional body of BPJS in relation with the fund management and development for health social security.
\end{abstract}

\section{A. INTRODUCTION}

National Social Security System is basically a national program aimed at providing certainty in protection and social welfare for all Indonesian people. Through this program, every resident is expected can fulfill the basic needs of living well when some problems occur and cause loss or reduction in income due to illness, accident, loss of job, entering old age, or retirement.

Article 4 of Law Number 40 of 2004 on National Social Security System stated that National Social Security System shall be based on the principle of cooperativeness, the principle of non-profit, the principle of openness, the principle of portability, the principle of mandatory participation, the principle of trust fund, and the principle that the result management of Social Security Fund will be used entirely for program development and for the greatest sake of the participants.

Referring to the provisions of Article 1 paragraph 6 in conjunction with

81 Yustisia. Vol. 6 No. 1 January - April 2017 Designing An Ideal Model For The Indonesia...

(C) 2017; This is an Open Access Research distributed under the terms of the Creative Commons Attribution Licensee (https://creativecommons.org/licenses/by/4.0), which permits unrestricted use, distribution, and reproduction in any medium, provided the original work is properly cited. 
Article 5 (1) of the Law that the Social Security Executor should be a separate legal entity and its formation should be through legislation. Juridical consequences of the Constitutional Court Decision of The Republic of Indonesia give a legal obligation to the government, namely (1) mandating the establishment of Social Security Agency under the law and (2) Implementing the institutional transformation of PT Askes (Ltd), PT Jamsostek (Ltd), PT TASPEN (Ltd) and PT Asabri (Ltd) to become Social Security Agencies. The transformation was followed by the transfer of participants, programs, assets and liabilities, employees, and also the rights and obligations (Muhammad Joni, 2005: 16). After being delayed for two years, the Parliament and the government finally approved the Law Draft of Social Security Agency (BPJS) into Law Number 24 of 2011 on Social Security Agency (hereinafter in this article referred to BPJS Law) on October 28, 2011.

Furthermore, in order to implement the decision of the Constitutional Court, the transformation of social security institutions is carried out by issuing PT Askes (Ltd) and PT Jamsostek (Ltd) from legal rule of Indonesian state owned enterprises or BUMN to public legal rule of non-profit autonomy, namely BPJS. While two others BUMN, namely PT Asabri (Ltd) and PT TASPEN (Ltd) remain as private pro-profit institutions and are subjects to the provisions of the Law Number 19 of 2003 on State-Owned Enterprises (SOEs) and Law Number 40 of 2007 on the Limited Liability Company. This dualism will continue until the transfer of Asabri and TASPEN program to Employment BPJS has been completed and the entire Indonesian population is ruled by the provisions of the National Social Security Act (SJSN) at least by 2029 (DJSN, 2014: 37).

Institutionally, BPJS is a legal entity in the form of 'a new legal entity' which is a subject to governance in accordance with the SJSN and the BPJS law and it is not a subject either to Law Noumber 19 of 2003 on State-Owned Enterprises (SOEs) or the Law Number 40 of 2007 on the Limited Liability Company. Looking at the provisions of Article 4 letter b BPJS Law, that the organizing of the national social 
security system is implemented by the non-profit principle. This means that BPJS in performing its functions and authority has followed the principle of business management which prioritizes the use of the results of development fund to provide the greatest benefit for all participants and not for profit as a primary goal. On the other side, in Article 10 letter d in conjunction with Article 11 letter b in conjunction with Article 43 paragraph 2 letter c BPJS mentions that BPJS has right to manage the Social Security Fund for the benefit of participants in the product of short-term and long-term investments, where the main purpose of investment activity gaining margin / profit is something that is essential (Sentosa Sembiring, 2010: 32). As mandated by the implementation of the provisions of Article 43 paragraph (2) letter c BPJS regarding with the management and development of fund assets for health social security has also been issued by Government Regulation Number 87 of 2013 on the Management of Fund Assets for Health Social Security.

Furthermore, as a 'new legal entity' which is public and may conduct business activity in its private domain, of course, it is more confusing in the legal concept of civil if within the provisions of article 47 of BPJS Law explicitly states that BPJS can not be bankrupted by the provisions of legislation on bankruptcy. Whereas in the business activities, the issue of bankruptcy is natural and inevitable when there is a mistake (miss-management) in running business portfolio management .

Another concern is the status of BPJS as a representation of the state in conducting business portfolio activities. If BPJS as a 'new legal entity' can not be bankrupted because of government label, of course this will lead to violations toward the equality principle among the parties in doing contractual relation.

Without prejudicing the good intentions of the goals of establishing BPJS in the Implementation of Social Security, it does not only aim on the pilot of early writing about ideal institution of BPJS, this paper also present an ideal format of BPJS (especially health aspect) institutionally in developing the Fund for Health 
Social Security so that its implementation does not cause legal problems in the future.

\section{B. PROBLEM STATEMENT}

Based on the concept of an ideal institution, the author wants to answer some questions that arise, among others, (a) what may institutional form of the national health security (BPJS kesehatan) conduct investment activities without crashing into the existing legal order?; (b) What is the forms and profit delivery mechanisms to participants when BPJS kesehatan manage the Fund for Health Social Security to get a significant margin.

\section{RESEARCH METHOD}

This research applies methods of empirical legal research because the data obtained through observations and interviews. Data was obtained from primary and secondary data. The primary data sourced from BPJS office in central Jakarta and BPJS office in Surakarta, Public and Health Practitioners and Academics. Secondary data obtained from a document that is personal and the public, as well as secondary data in the field of law. Secondary data is collected through literature and content analysis of documents, archives, legal materials. The collected data are arranged inductively by identifying, according to classified the issues and research purposes, then resulting conclusion.

\section{RESEARCH RESULT AND DISCUSSION}

\section{Lesson Learned From Some Countries}

No country in every corner of this world which do not want welfare as a goal (welfare state) (Robert Urbe, 2012: 9). Welfare then perceived when all citizens can meet their basic needs easily to avoid the risks that threaten their lives. To achieve this goal, one of the obligations that must be done by the state is implementing social security for each resident comprehensively (Michael O'Brien, 2008: 1-4). 
Implementation of social security, at first pioneered by Otto von Bismarck in Germany in 1883 principally intended as an effort to realize the people welfare. Today the Social Security System has been growing around the world with various modifications, according to the circumstances, needs and even the political and economic system in each country (Sulastomo, 2011: 25). Here are some concepts for implementing social security in some countries, especially relating to the management of social security fund.

\section{A. Fund Management of Health Social Security in Germany.}

As an innovator in the modern implementation of social security, it is not surprising that every country across the global world refers to and modifies the system of social security implementation (soziale Sicherheit) which has been implemented in the Germany since the enactment of Imperial Decree in 17 November 1881 on the initiative of Otto von Bismarck.

At the beginning, the burden of social security implementation (soziale Sicherheit) in the Germany rests entirely on the state based on three main principles: (1) Payment of premiums by the participants (2) Involvement of the State in its investment fund and supervision, and (3) Proportional and balanced participation by participants, employers and governments in making any policies relating to social implementation .

Today, the concept of social security implementation in Germany metamorphosed to a better direction, where it is characterized by the existence of the principle of self-government. This principle aims to release the state involvement in the management of social security fund, so that the burden of management and development of the social security fund shifted from the state to enterprises (corporations) under public law.

Furthermore, special identity of the self-government principle is the active participation of the participants and employers independently without involving 
the state in the management and development of social security fund. State role was reduced to the level of monitoring the course of management and development of social security fund in accordance with the established corridor. The implementation of the state supervision in the social security implementation in Germany is done through the Ministry of Health (Bundesministerium für Gesundheit) for social security related to labor and Ministry of Labor and Social Affairs, meanwhile the Bundesministerium für Arbeit und Soziales is for social security related to health care.

B. Fund Management of Health Social Security in the United Kingdom

The escalation of the labor movement in the United Kingdom in early twentieth century has shed new light for the presence of the state in creating a social policy that is pro-labor. After experiencing a long debate under the liberal government of Herbert Asquith at that time, the British Parliament finally releasing The Old Age Pensions in 1908 (Margaret S. Gordon, 1988: 27).

Then three years later, it appeared regulation that its coverage more widely known as the National Insurance Act of 1911. The born of this regulation inspired by David Lloyd George (the Finance Minister of the United Kingdom in the era of Herbert Asquith). He made a visit to Germany in 1908, at which time Budget Speech delivered in 1909, David Lloyd George, gave a statement that England should not only put on the same level with Germany in the field of armaments but also in the field of social welfare.

The presence of the National Insurance Law of 1911 provides the first opportunity to the labor class in England contributing into the insurance system to protect their rights when they were sick (ill) and when they were not working (unemployment). Broadly speaking, this can be regarded as foundation stone in realizing the concept of welfare state in the United Kingdom, both regulations may be referred as a milestone for the born of the social security concept in the United Kingdom. 
In its journey, the National Insurance Law of 1911, has undergone several changes / amendments in the framework of adjustment with politics in the United Kingdom. For now, the management control of social security in the United Kingdom are run under Department for Work and Pensions for social security in relation with employment and Ministry of Health (Department of Health) through the National Health Service (NHS) for social security related to health.

As an imitation of the Bismarckian model of Germany, the United Kingdom has a social security system of health since 1948, known as the National Health Service (National Health Service). Each year the National Health Service (NHS) is targeted to provide perfect service and wider range of coverage services covering the entire United Kingdom citizens.

Armed with a legal shade of The Health and Social Care Law of 2012, the United Kingdom has been elected by The Commonwealth Fund Agency to be a country which has the best social security system if it was compared with ten other developed countries (Australia, Canada, France, Germany, Netherlands, New Zealand, Norway, Sweden, Switzerland and the United States of America) in providing health services through its NHS.

Besides it is known as publicly funded healthcare system, the method of fund-raising (fund accumulation) used by the NHS is by using the premium offered by the government through taxes paid by residents. Meanwhile, the community of workers and the employers do not have to make premium payments. This may implies that the government fully control the administration of the social security (health care system).

C. Fund Management of Health Social Security in United States of America

Management of social security in the United States of America is fronted by an independent agency known as the Social Security Administration (SSA). The Institutions Social Security Administration (SSA) was formed with the provisions of the Social Security Act rests after Americans experience a severe economic 
depression shocks in 1930. At the beginning of its presence, the Social Security Administration (SSA) program is intended only for servicing the payment of pensions (retirement benefits and only for the worker) toward the population aged 65 years or above (SSA Publication, 2015: 1-10).

Institutionally, the Social Security Administration (SSA) as an independent agency headed by a commissioner appointed by the President and shall be approved by Congress. Mainly, the responsibility of the commissioner include development of policies, direction and administration of the programs, interpretation and evaluation of the programs, maintenance of relationships with the news media, research which has oriented studies on economic insecurity issues in American society and development to promote social security and economy through social insurance/security and some related programs (Robert Walker, 2005: 63)

In its development, the Social Security Law was recorded has undergone several amendments with the aim of adding a service program suited to the demands and needs of residents of the United States of America. During the reign of President Lyndon Baines Johnson in 1965, the Social Security Law also experienced an amendment relating to the addition of health care program (Medicare and Medicaid).

As a national and centralized institution, the Social Security Administration (SSA) in its fund management of health social security, involves two fundamental elements, namely the collection of fund (fund accumulation) and portfolio diversification. Fundraisers (fund accumulation) refers to the gathering of social security fund obtained from the payment of premium taxes, which already included the social security fund, while portfolio diversification is the development activities of social security fund which have been collected through the social security trust fund (Laurence S. Seidman, 1999: 1-10).

In doing the portfolio diversification of social security fund, the Social 
Security Administration (SSA) uses the services of investment firms (through a super tight selection). Since it is a public fund, the substance of the agreement made between the Social Security Administration (SSA) with the chosen investment firm is conducted under some restrictions approved by the Board of Trustees. The restrictions include investment types that are safe and have low risk of loss, the amount of maximum value and minimum investments will be utilized by the elected investment company, and so forth.

\section{Fund Management of Health Social Security in Japan.}

Typology of social security system in Japan is very interesting when it is seen from its need whether the social security system mandatory or nationwide. That view can not be separated from the culture of healthy living of Japanese society itself which was already high. Thus, it positively impacts to the high rates of life expectancy and the low medical expenses per capita compared to other industrialized countries.

Based on the data taken from the National Institute of Population and Social Security Research in 2013, Japan had a community with the highest life expectancy in the world, $25.0 \%$ of the population aged over 65 years in 2013 will rise to $40 \%$ in in 2060 , then the increase of the oldest, inter alia the population aged over 75 years from $11 \%$ in 2010 will increase to $27 \%$ by the year 2060 .

The authority for managing the social security system in Japan to be the responsibility of The Ministry of Health, Labour and Welfare (National Institute of Population and Social Security Research, 2014: 1-10). In conjunction with the implementation of social security, this Ministry is setting national standards and promoting social security programs that are considered necessary to be implemented in national scale. While on the other hand, local government such as prefectures and especially cities (towns and villages) is possible also to have social security offices and community health centers to execute and implement social security services as a consequence of the implementation of regional/local 
autonomy.

Providers of social security services such as hospitals and clinics for health care, child care and institutions for long-term care of elderly, rehabilitation centers and centers for the disabled, and others may be done by both state institutions and private institutions which are non-profit . In the hierarchy of both social security health institutions (both state and private) are operated and strictly supervised by the Ministry of Health, Labour and Welfare and Local Government.

In broad way, there are five social insurance systems run in Japan, namely (1) Public Pension Insurance, (2) Health Insurance, (3) Long Term Care Insurance, (4) Employment Insurance, and (5) Work Accident Insurance, From all these insurances, all citizens are registered in the public pension insurance and the medical insurance held by the Government. Universal coverage possessed by both public pension insurance and health insurance are main characteristics of the social security system in Japan. It is not much different from the United Kingdom. After social security fund is collected through taxes premiums paid by society then it is managed professionally by The Ministry of Finance in Japan.

\section{Indonesian Model: Supposed a Suitable Model}

1. It can be seen that the concept of BPJS actually clone / imitate the implementation of social security owned by the United States of America (Academic Text of The Bill of Social Security Agency).

However, if we do a deeper research, particularly related to the development issues of fund for social security health, we will find the basic differences between them. The independence and authority given to the Social Security Administration (SSA) can be said is far different from the independence and authority possessed by BPJS as 'a new legal entity'.

Legislative process which base on the BPPS Law along with its derivative legal products seems feel ashamed to imitate (fully) the procedures and mechanisms for the development of the social security fund through investment activities 
undertaken by the Social Security Administration (SSA). Although Government Regulation Number 87 of 2013 on the Management of Fund Assets for Health Social Security has been issued but within the provisions of these regulations only regulate investment products which are allowed to be used in the fund development of health social security (Government Regulation Number 87 of 2013 on the Management of Fund Assets for Health Social Security), whereas the arrangements regarding procedures and mechanisms for electing investment firms and profit-loss distribution mechanisms from the development activities for social security fund is not mentioned in this regulation.

In order to develop fund for health social security which is oriented for the participants welfare, here it can be submitted several alternatives of institutional models as follows:

\section{Public-Private Partnership}

World Bank provides a definition for public-private partnership as an "A long-term contract between a private party and a government agency, for providing a public asset or service, in which the private party bears significant risk and management responsibility" (The World Bank, 2012 : 11). As a relationship based on agreement between the government and the private sector in public service implementation, public-private partnership can be used as an institution model in the framework of fund development for health social security.

Johannes Jütting in his paper stated that the use of public-private partnership model in the management of social security is more suited to be applied by developing countries. Moreover, Johannes Jütting argued that in general in several developing countries (including Indonesia) competence and expertise of human resources owned by the government (public) as the main administration actor of social security mostly do not meet the standards. Therefore, it is necessary to have partnership with the private sector (private), which is believed it can provide support to the government side (Johannes Jütting, 2002: 1-20) 
The writer argues that this model is more flexible to be applied without doing a lot of changes in terms of regulation. Briefly, the model of public-private partnership can be described with the following illustration.

Emphasis in the model of public-private partnership is relying on:

a) Agreement Restriction

Restrictions in the case of this agreement mean restrictions on investment products that are allowed and prohibited to be developed by the investment company as it is regulated in Article 30 and 31 of Government Regulation Number 87 of 2013 on the Management of Fund Assets for Health Social Security.

A chosen Investment Company (Private Firm) in developing their fund for health social security is obliged to follow all provisions of the agreement signed by the BPJS directors.

The agreements which are made here, beside to arrange the above conditions they should also mention financing mechanism of the chosen investment company, liability of the selected investment company and the dispute settlement mechanism as well.

b) Authority Expansion of The National Social Security Board (DJSN)

As an organ whose function is to assist the President in formulating public policies and synchronizing implementation of the national social security system. DJSN through this model needs to expand its authority, by which such authority is actively involved in the determination of investment firms that will be selected.

Active involvement here started from making the selection guidelines, the fit and proper test, until the sanctions to investment firms that will be selected. 


\section{c) Profit Redistribution to The Participants}

Social security fund is actually fund owned by the participants as mentioned in Article 15 of Government Regulation Number 87 of 2013 on the Management of Fund Assets for Health Social Security.

Based on the affirmation above, the development result of the social security fund intended entirely for the program development and for the greatest sake of the participants so that the profit distributions are balanced (equal and fair). This is mandatory and absolutely fulfilled by BPJS both for program development and participants sake.

From the search of BPJS Law along with provisions of Government Regulation Number 87 of 2013 on the Management of Fund Assets for Health Social Security, it has not mentioned in detail the benefit redistribution to be received directly by the participants who are in fact as the fund owners.

\section{Establishment of Trustees Institution}

As it is mentioned in the provisions of Article 4 Law Number 40 of 2004 on National Social Security System that one of the organizing principles of the National Security System anchored in the principles of trust fund.

The principle of a trust fund implies that the fund collected from the participants contributions are entrusted to executor agencies to be managed as well as possible in order to optimize the fund for the participants welfare.

Institutionally, the management concept of mandate fund (hence called trusts) is already in accordance with the provisions of Article 34 of the Constitution of the Republic of Indonesia of 1945 because it transfers the responsibility of implementing the social security entirely to the state.

When it is examined deeply, the concept of trusts is already developed in Europe in the Middle Ages as "mutual benefit societies" where its formation was 
based on between religious brotherhoods, economic (guilds, corporations) and social (trade guilds) (H Thabrany 2009: 36). In the national context, the concept of trusts has also long been run by our society as a social gathering, jumputan (Java), Subak (Bali), and so forth.

From the community sake and return back to the community (in the form of services and benefits), the model of Trustee Institution in relation to the fund management of health social security can be described through the following illustration

From the above illustration, it can be stated that the Government should issue a legal basis with its synchronization and harmonization of relevant regulations in terms of changing the organ (institutionally) from Social Security Agency to Trustee Institution. This is an institution whose ownership is divided proportionally both participants (through the paid contributions), the Government (through the gBUMN and government capital), as well as third party funding (through grant).

This institution can undertake the development of social security fund which has been raised through a diversified investment portfolio, with a record that it must obtain approval from the National Social Security Council considered as the Board of Trustee

Profit gained from the result of the fund management for health social security can be redistributed equally and fairly (1) To the participants through improved services, cash back, incentives; (2) To the Government and then to be used as operating fund for health services, hedge fund, and others; and (3) To third parties grantor through annual reports which are compiled in accountable and transparent order.

The legal framework in this matter need to be formulated by the government to carry out a series of steps that are necessary be taken. The most important thing 
to be formulated is drafting regulations that may be necessary as a legal umbrella to run Institution of Trustee

\section{E. CLOSING}

Based on the research results it can be stated some conclusions as the following

1. The implementation of social security is an absolute obligation (compulsory obligation) of a country as the fulfillment of social rights to each citizen. Within the framework of ensuring the implementation of an integrated, cohesive and comprehensive national security system, a legal shade is issued through SJSN Law and BPJS Law along with its underneath regulations as mandate translation of the 1945 Constitution after amendments. Based on the research which is still a stub, the writer found some problems in the implementation of social security conducted by the Social Security Administration Body (BPJS) institutionally, particularly regarding to the development management of social security fund.

2. Through this research, it can be formulated two institutional models of the Social Security Administration Body (BPJS) in relation to the management and development of social security fund. They are a model of Public-Private Partnership and a model of Trustees Institution. The models are presented with their advantages and disadvantages by which they apparently can be used as an alternative option in the management and development of social security fund which in turn provide maximum benefit for the participants of social security.

\section{BIBLIOGRAPHY}

Academic Text of the Bill Draft of Social Security Administration Body (BPJS) 
Dewan Jaminan Sosial Nasional (DJSN), 2014, Paham Transformasi Jaminan Sosial Indonesia (Understanding the transformation of Indonesia Social Security), Jakarta: CV Komunitas Pejaten Mediatama

Gordon, Margaret S., 1988, Social Security Policies in Industrial Countries, Cambridge: Cambridge University Press

Government Regulations Number 87 of 2013 on The Management of Fund Assets for Health Social Security

Joni, Muhammad, 2005, Menuju Jaminan Sosial untuk Semua dan Pro Poor: Hak Konstitusional yang (masih) Terabaikan (Going to Social Security for All and Pro Poor : Constitutional Right which is (still) Ignored), Jurnal Mahkamah Konstitusi Republik Indonesia, Volume 2 Number 3, November 2005, Jakarta

Jütting, Johannes, 2002, Public-Private Partnerships in The Health Sector: Experiences from Developing Countries, Extension of Social Security (ESS) Working Paper Series Number 10, Geneva: Social Security Policy and Development Branch International Labour Office

Livingston, Steven G, 2008, U.S. Social Security a Reference Handbook, Santa Barbara: ABC-CLIO, Inc.

National Institute of Population and Social Security Research, 2014, Social Security in Japan, Tokyo

O'Brien, Michael, 2008, Poverty, Policy and The State - The Changing Face of Social Security, UK: The Policy Press University of Bristol. 
Seidman, Laurence S., 1999, Funding Social Security: A Strategic Alternative, Cambridge: Cambridge University Press

Sembiring, Sentosa, 2010, Hukum Investasi (Investment Law), Bandung: Nuansa Aulia.

Social Security Administration, 2015, The History of Social Security, Baltimore: SSA Publication.

Sulastomo, 2011, Sistem Jaminan Sosial Nasional: Mewujudkan Amanat Konstitusi (National Social Security System: Achieving Constitutional Trustee), Jakarta: $\quad$ PT Gramedia Pustaka Utama.

Thabrany, Hasbullah, 2009, Badan Penyelenggara Jaminan Kesehatan Nasional: Sebuah Policy Paper dalam Analisis Kesesuaian Tujuan dan Struktur BPJS (National Health Security Agency: A Policy Paper in The Adjustment Analysis of BPJS Goals and Structures), Posisition Paper bagi the Hatta Project kerjasama antara Perkumpulan Prakarsa dan the Asia Foundation Maret 2009

The World Bank, 2012, Public-Private Partnerships Reference Guide, Washington: The World Bank

Urbe, Robert, 2012, The Future of The Welfare State (A Compartive Study in EUCountries), Lambertus-Verlag, Freiburg im Breisgau

Walker, Robert, 2005, Social Security and Welfare Concepts and Comparisons, UK: Open University Press.

\section{Regulation:}

Decision of Constitutional Court of Republic of Indonesia Number 40 of 2004 on National Social Security System toward the 1945 Constitution of Republik 
Indonesia

Law Number 40 of 2004 on National Social Security

Law Number 24 of 2011 on Social Security Administration Body (BPJS) 